\title{
THE EFFECTS OF EPICS ON INTERCULTURAL AWARENESS OF SECOND LANGUAGE LEARNERS AT SCHOOL OF FOREIGN LANGUAGES ${ }^{1}$
}

\begin{tabular}{|c|c|}
\hline & Nuriye KÜLAHLI² \\
\hline Article Info & Abstract \\
\hline $\begin{array}{l}\quad \text { Keywords } \\
\text { Literature } \\
\text { Culture in ELT } \\
\text { Epics } \\
\text { Intercultural Awareness } \\
\text { Second Language } \\
\text { Learners }\end{array}$ & $\begin{array}{l}\text { This research study was aimed to determine whether the epics have effects } \\
\text { on intercultural awareness of second language learners at the School of } \\
\text { Foreign Languages, Selcuk University. It was conducted in two prep } \\
\text { classes including } 21 \text { and } 19 \text { students to determine whether using epics was } \\
\text { beneficial for intercultural awareness of second language learners during } \\
\text { the foreign language learning process. The experimental group including } \\
21 \text { students was taught two English and two Turkish epics and related } \\
\text { activities were done. The control group consisted of } 19 \text { students and no } \\
\text { specific study for intercultural awareness was done. The students in that } \\
\text { group got the cultural information from the coursebook. Both groups were } \\
\text { given a questionnaire as a pre-test and a post-test. The test consisted of } \\
\text { three open-ended questions related to the attitudes of students towards the } \\
\text { target culture. During the study, the students were observed, and their } \\
\text { behaviours and opinions were recorded by the researcher. The results } \\
\text { showed a significant difference in the mean gains of the samples. Teaching } \\
\text { epics proved to be effective on students' intercultural awareness as second } \\
\text { language learners while learning a second language. }\end{array}$ \\
\hline
\end{tabular}

Cited as APA: Külahlı, N. (2021). The effects of epics on intercultural awareness of second language learners at school of foreign languages. International Journal of Current Approaches in Language, Education and Social Sciences (CALESS), 3(2), 265-299.

\section{Introduction}

Culture symbolizes language and is summed in the economic, religious, and philosophical systems of a country. While learning a foreign language, it is likely for its learners to need cultural information for better communication (Byram and Flemming (1998: 2), Byram (1990: 76-87). Language teachers have been more interested in the practical aspects of communication. They often treat culture as supplemental or incidental to "the real task" (Fantini, 1997: x). Douglas (1994: 9) points out that learning the language of another culture is an effective way to increase one's information.

\footnotetext{
${ }^{1}$ This study is a part of MA thesis written by the author under the supervision of Prof. Dr. Ahmet Ali Arslan in the department of English Language Teaching at Necmettin Erbakan University, Konya.

2 (Delcuk University, Konya, Turkey, nuriye.kulahli@selcuk.edu.tr
} 
Anticipating preconceptions and stereotypes from another culture's viewpoint requires knowledge about the myths and widely "understood" perceptions from that culture's viewpoint. It is also important to know the right way to get more information about the culture in question so that the teaching/learning resources will be appropriate. Corbet (2003: x, 2) claims that the language learner moving between cultures is an intercultural learner.

It is expected for learners to have intercultural awareness between the native and the target language. It is an ability of learners that might be gained through the language learning process. Pedersen (1936: 9) explains awareness as the ability to accurately judge a cultural situation from both one's own and in the other's cultural viewpoint. Such awareness requires learners to have awareness of cultural and linguistic differences, interest in the culture, sensitivity to the myths and stereotypes of the culture, appreciation of the importance of intercultural teaching.

Up to now, two main perspectives have influenced the teaching of culture in the field of English language teaching. One pertains to the transmission of factual and cultural information such as customs and habits of target language speakers. Learners are immersed in cultural readings, films, videotapes, recordings, realia (cultural artefacts) and personal anecdotes (Corbett, 2003: 194). This approach, however, has certain limitations. Kan (2006: 1) points out that this approach does not mainly aim to furnish the learners with skills to discover, interpret, and relate cultural knowledge. The other perspective claims that language learners need to learn how to learn about other cultures rather than factual knowledge about a specific culture. In other words, equipping the learners with skills and strategies that will enable them to discover cultural information is more beneficial for language learners than stuffing language learners' heads with facts about a specific culture (Kan, 2006: 1). The learning tasks are shaped in a way that promote curiosity, tolerance, sensitivity, and empathy in learners. Reinhold (2002: 73) points out that the tasks are not aimed to transfer cultural facts but to provide learners with opportunities to learn how to learn the culture of others and to enjoy learning other cultures while developing tolerance and interest.

The reason for the use of cultural content in the classroom is that it will foster learner motivation (McKay, 2000: 7). McKay believes that there should be a variety of cultures in the materials and not only an overload of western culture in ELT classrooms. McKay (2000: 9-10) identifies three types of cultural materials: target culture materials, learners' own culture materials and international target culture materials. As she suggests, the best one is the international target language materials, which supposedly 
cover a variety of knowledge from different cultures all over the world using the target language. That will most probably increase the learners' interest rather than imposing only one culture all the time and prevent learners from having the fear of assimilation into a specific culture and help them respect other people's cultures. Students' own culture should be discussed together with the target culture. In other words, the home culture and the target one should be integrated. Stuart and Nocon (1996: 435) refer to this integration as 'Color Purple'. According to Stuart and Nocon, this synthesis is created when one becomes aware of one's cultural lens (e.g. blue) through the recognition that a person from another culture has a different lens (e.g. red). Neither person can escape his or her cultural lens, but each can choose to overlap lenses (e.g. purple) to understand better the other's perspectives and arrive at shared meaning.

There are a lot of activities we can use in our classrooms to create interest in the target language by using cultural content. The key point is that we should create a relaxing environment where our students can discuss their own culture together with the target culture in meaningful and communicative tasks and activities. This will ensure that students are doing something with a purpose in their minds. Pedersen (1936: 4-5, 13) suggests that experiential methods emphasize less- formal, field-based experiences and a two-way interaction between teachers and learners. Teaching increased awareness often relies on experiential exercises such as role-plays, role reversals, and other approaches such as bicultural observation and experiences, and questionsanswers-discussions. Sometimes critical incidents and brief case studies from the culture can be considered to increase learners' awareness of the culture.

Role-play (Douglas, 1994: 174), (Donahue and Parsons, 1982: 359-365), (Kodotchigova, 2002: 8), (Kaplan, 2006: 32-33) is a useful instructional technique in a sociocultural approach. Negative Etiquette" (Corbett, 2003: 110; Kan, 2006: 2) is another enjoyable activity. The familiar Venn diagram is a useful graphic organizer for comparisons. Making comparisons between different story contexts, between stories and their own life experience helps children gain insight into cultural concepts while learning the vocabulary of comparing and contrasting. Stories that portray the exotic or the quaint minimize the shared universal human experience and stories that fail to show diversity within groups build stereotyped images of other cultures (Derman-Sparks, 1993-4: 70(2); Y1lmaz \& Özkan, 2015: 273-274).

Within the past decade, the problems resulting from not teaching culture with language have started to be recognized. Language teachers try to avoid turning out 
fluent fools by deliberately helping students learn to experience reality in a new way through culture. Many international and national foreign language associations have begun to address this problem by incorporating culture into their standards. In 1996, TESOL published as its third goal in ESL Standards for Pre-K-12 Students "to use English in socially and culturally appropriate ways". Additionally, the national standards for foreign language education developed in part with ACTFL were based on "knowing how, when and why to say what to whom." The national standards were created with the ultimate goal of foreign language teaching being "the ability to communicate in meaningful and appropriate ways with users of other languages." Many linguists and interculturalists have started to address this problem with series such as New Ways in Teaching Culture (Fantini, 1997: 17). In Turkey, there have recently been some important studies related to the intercultural awareness of second language learners (Onalan, 2005; Şahin, 2005; Başbay \& Bektaş, 2009), Yılmaz and Özkan, 2015; Tutal, 2016; Tosuncuoğlu, 2019, Zorba \& Çakir, 2019; Özışık, Yeşilyurt and Demiröz, 2019). These studies carried out in the Turkish context concerning the teaching of culture in ELT classrooms demonstrate that second language learners should also learn the target culture while learning the target language.

Literature is considered one of the best ways used in teaching culture. Since the 1980s, literature has been used in the teaching of EFL and has attracted more interest among EFL teachers. Furthermore, it has been realized that literature can be used to develop the critical thinking competence of learners and their language skills (Kaplan, 2006: 22). Besides, the books published in the 90 s, namely Language through Literature by Bassnett and Grundy and Literature by Duff and Maley marked that literature shall find its rightful place in ELT (Kaplan, 2006: 25). Brumfit and Carter (2000: 182) states the purpose of using literature in language classes as it will increase all language skills and extent linguistic knowledge by giving evidence of extensive and subtle vocabulary usage, and complex and exact usage. Collie and Slater (1996:3) point out that literature is authentic material. In some texts, there are "authentic" samples of language, such as travel timetables, city plans, cartoons advertisements and newspaper or magazine articles. Thus, students are exposed to a language that is genuine as in the society and which can be managed in the classroom context.

Literary texts such as radio programs, videos, or newspapers are important resources for learners to learn the culture and the way of life of the country. Novels, plays, epics, and short stories are full of vivid context with their characters that come from different cultural backgrounds. Roger Rollin (1989: 17-18) states that literature should be 
durable, that is, it should take the form of a written text, a recorded utterance, or something transmitted orally like a saying, joke, myth, or epic poem. Literature as a reading material can have a powerful effect on language learners as literature is in any way the reflection of a culture and its elements. Three models advise literature in ELT. These are the cultural model, personal-growth model, and language model. Carter and Long (1991: 28) in Kaplan (2006: 25) suggests that "the Cultural Model" views a literary text as a product. This means that it is threaded as a source of information about the target culture. This model is considered as the traditional approach to teaching culture. Such a model requires learners to explore and interpret the social, political, literary and historical content of a specific text. Works of literature are the relics of culture and through their study students can understand and appreciate cultures and ideologies different from their own in time and space.

Through reading literature, the students can gain intercultural awareness, empathy, tolerance for diversity, and emotional intelligence. Ghosn (2002: 171) made a study on the possible contributions of literature to language classrooms. She claims that there are many reasons to use authentic literature in EFL classes as it is clear from the evidence of myths, epics, legends and folk tales that throughout many centuries people were, are and will be interested in stories. Similarly, Kachru in Brumfit and Carter (1986: 140-149) points out that the use of literature develops cultural awareness in students. Literary texts contain copious examples of practices, attitudes, and beliefs of people across the cultures of the world. While these examples help to promote a comprehensive view of culture, they can raise problems regarding the notion of culture in the target language, as well. This is because English is used across the world as a first and second language and a stereotypical view of the target culture can endanger the use of literature in second language classrooms.

Epics are one of the valuable sources of literature. Elcin (1997: 90-99) claims that they are epos, stories, myths, historical events, adventures, legends, speeches, poems, advice, biographies, tales, and old sayings. Tural (1999: 39) and Taflı (2006: 2) points out that one of the most important elements, which penetrate culture, is undoubtedly epics with historical, literary, social and ethnological values. Epics may be valuable materials in ELT classes as a useful guide to the paths of intercultural awareness. However, reading the culture is not useful for learners to be aware of the culture. That is just the information transfer. It might not help learners' intercultural awareness. It can be asserted that learners should be aware of the intercultural similarities and differences. It is the teachers' job to make the learners be aware of them. It may be 
useful for students to read Turkish epics which display similarities in English epics. Students can be exposed to both epics of the nations and asked to see the similarities and differences between them.

The problem which necessitated this study is that teaching target culture as information transfer lacks the advantages which teaching culture with the help of literature offers to second language learners. This study aimed to research whether using epics proves to be effective on the students' intercultural awareness. In this respect, it can also set light to answer the following research questions:

1-Is there an influence of teaching epics on students' intercultural awareness?

2- Which culture teaching style is better for students' intercultural awareness: using epics or information transfer from the books?

The purpose of this study is to find out whether students' intercultural awareness could be enriched through an instruction that emphasizes the role of literature using epics in teaching culture. Namely, this study seeks to find out the difference between two distinct target culture teaching styles: teaching culture through epics and teaching culture as information transfer in the coursebook. To that end, this study examined the second language learners' intercultural awareness through teaching epics in a classroom context.

\section{Method}

The study aimed to identify the effects of epics on intercultural awareness according to the views of prep students at the School of Foreign Languages, Selcuk University. To determine the effects of epics on these students' intercultural awareness qualitative research method was used. The evaluation of the instruction process was performed through the qualitative research methods. These were semi-structured questionnaire and observation notes. It was aimed to collect data thoroughly from the students with the help of a semi-structured questionnaire including three open-ended questions.

In the analysis of the data, the descriptive analysis technique was used. The quotations from the semi-structured questionnaire were used. The instruction of the study was performed by the researcher in two groups and the instruction in the experimental group lasted four weeks. One week before the instruction, the questionnaire was given to both the experimental and the control group. During the instruction weeks, two English epics and two Turkish epics were the focus in the experimental group. The aim was to attract the attention of the students to the similarities and differences 
between two epics from different cultures. In the control group, the lessons continued according to the school curriculum, no particular study was performed.

\subsection{Participants}

The study took place at the School of Foreign Languages (SOFL) in Konya during the spring term of the 2007-2008 academic year. Since the study required two classes, one experimental group and one control group were selected for the study. Each class had almost the same placement test average, which is why; they were called as Class 39 and 40 , following one another according to test results.

Considering nearly all the students have negative attitudes towards the target culture, it was decided to choose one experimental class as an example. The pre-test including three open-ended questions was given to two classes to see the attitudes of students towards the target culture. The answers given to the questions about the target culture showed that the students were mostly against English culture. The students gave similar answers to the questions given. Thus, the experimental and the control groups were chosen randomly. According to the random choices of the groups, class 40 was used as the experimental group and class 39 was used as the control group.

The number of students in the experimental group is 21. In the control group, the number of students is 19. There were 6 girls and 15 boys in the experimental group, and 7 girls and 12 boys in the control group. All the participants are taking the preparatory year for the first time.

\subsection{Data Collection Instruments}

Classroom observation notes and a semi-structured questionnaire were used during the study. With the help of a semi-structured questionnaire, it was aimed to understand the attitudes of students to the target culture. The semi-structured questions were prepared with the help of seven instructors, who are experts in their fields, to make the instrument reliable. The questionnaire including three open-ended questions was related to English culture. The students were asked to answer the questions, express their opinions, and give the reasons for the answers. The questionnaire was held in Turkish to express their thoughts in their native language. It was used as the pre-test before the study both in experimental and control groups to see the attitudes of students to English culture. The questionnaire was also used as the post-test after the study to see whether the opinions of students changed or not. 
Classroom observation was held in a naturalistic classroom setting. The students were not controlled in any way. Whole classroom observations were recorded without preparing any preliminary categories to look at. The data were collected through a video camera. A video-camera recording was used to record oral communication in the classroom with the researcher and the students. The verbal attitudes of the students toward the target culture were observed and every changing behaviour was recorded. The recordings were transcribed after the observations. To provide reliability, two independent listeners were asked to listen to the recordings and read the transcripts. Moreover, observation notes were performed by the researcher during the instruction process.

The instruction of the study was performed by the researcher. The researcher was the teacher of the experimental and the control groups. The data were collected and interpreted by her. Moreover, the classroom observation was held by the researcher herself during the lessons at SOFL.

\subsection{Data Collection Procedures}

Data collection procedures were categorized into three parts: Pre-Procedure, In-Study Procedure and Post-Study Procedure. In the first part, it is explained how two groups were selected as experimental and control groups. In the second part, the instruction of the study is introduced in the experimental group week by week. The last part explains the post-study procedure.

\subsubsection{Pre-Procedure}

Two classes, Prep 40 and Prep 39 were selected as the experimental and control groups. A semi-structured questionnaire including three open-ended questions was given to the students in each class and the students there were asked to answer them in detail to see their attitudes to English culture (See Appendix I). The questionnaire showed that the students both in Prep 40 and Prep 39 were mostly against the target culture. Thus, one class was chosen randomly as the experimental group. It was Prep 40. Prep 39 became the control group.

\subsubsection{In-Study Procedure}

This part of the study includes the instruction of the study. The instruction lasted four weeks. During the instruction, the experimental group was presented with two English and two Turkish epics. The students were recorded by a video camera during the study to see their changing behaviour and attitudes toward the study. The instruction process was explained week by week in the following sections. In the first 
week, the students were first asked to read "Beowulf" and "The Book of Dede Korkut (Basat and Tepegoz)". The aim was to attract the students' attention to the similarities and differences of the two different epics. The aim was to see the attitudes of students towards English epics. Related activities such as guessing the subject of the epic, putting the pictures in the correct order, matching the paragraphs with the paragraph topics and answering the comprehension questions were performed (See Appendix II).

In the second week, students were asked to find the similarities and the differences between these two epics with the help of a Venn diagram. They just used words to complete the diagram (See Appendix III). Afterwards, the students were asked to complete a chart in the following by making sentences with the words in the Venn diagram to see the similarities and differences better (See Appendix IV). The aim was to make the students aware of the similarities and differences between an English epic and a Turkish one. Then, students were asked to perform a role-play. The aim of the role-play was to make the students have an interplay between the two epics. The students were exposed to be the characters of the two epics and act out a dialogue related to the given situation (See Appendix V).

In the third week, the students were first exposed to read "The Paradise Lost" and "The Altaic Creation Epic". They were asked to perform related activities such as guessing the subject of the epic, putting the pictures in the correct order, matching the paragraphs with the paragraph topics and finding true/false statements (See Appendix VI).

In the fourth week, the students were first asked to find the similarities and differences between the epics with the help of a Venn diagram. This activity aimed to make the students aware of the similarities and differences between the two different cultures' epics. The students made sentences using the words in the diagram (See Appendix VII). In the second lesson, the students were asked to perform a role-play "Here and There". In "Here", students were asked to imagine that a given character given in the epic lived in the contemporary world and they were to predict the character's behaviour in a given situation. In "There", students were asked to place themselves in the story's reality. They acted up a role-play presenting how they would have handled a given situation or what they would have said (See Appendix VIII).

However, the students in the control group were not exposed to anything related to the epics. They continued to learn the things in the coursebook as in the curriculum. 
In the coursebook, the things related to the target culture were just information transfer and it was given in the "Culture Corner" parts.

\subsubsection{Post-Study Procedure}

After the study, both experimental and control groups were given the same questionnaire. The results of the groups were examined to see whether the opinions of the students about the target culture have changed or not during the process. Moreover, to see the opinions of the students in the experimental group related to the study, a lesson diary was used by the researcher. The students were expected to write their ideas according to the given prompts. The lesson diary was in students' native language so that the students could express themselves more comfortably (See Appendix IX).

\section{Findings}

The results of the study are based on the analysis of pre-test and post-test scores of experimental and control groups, the classroom observation, and the lesson diary after the study. The interpretations of the results were given with the help of the students' opinions given in the questionnaire as the pre-test and the post-test.

\subsection{Analysis of Pre-test Scores of Experimental and Control Groups Before the study}

The students in both experimental and control groups were asked three open-ended questions in the semi-structured questionnaire. They were all related to English culture. The aim was to see the attitudes of the students towards the target culture. The students were expected to answer the questions in detail. Naturally, there were not only negative opinions but also positive ones among the answers. Yet, in this study, we aimed to specify the negative attitudes of the students about the target culture. Thus, the results were based on the negative answers to the questions.

\section{Question 1: Is learning English culture necessary while learning English?}

For this question, the results are analyzed both in experimental and control groups. In the experimental group, 9 out of 21 students were strongly against the necessity of learning culture in learning English. In the control group, 6 out of 19 students were against the necessity of learning English culture while learning English. Therefore, between the experimental and control groups, there is a slight difference related to the percentages of the students' negative and positive answers. The difference is shown in the table below: 
Table 1. Pre-test scores of experimental and control groups for question 1

\begin{tabular}{llll}
\hline Group & $\mathbf{N}$ & Negative \% & Positive \% \\
\hline Experimental & 21 & 42.9 & 57.1 \\
Control & 19 & 31.6 & 68.4 \\
\hline
\end{tabular}

According to Table 1, 9 (42.9\%) out of 21 students in the experimental group and 6 $(31.6 \%)$ out of 19 students in the control group believed that English culture was not necessary for learning English. This shows that the number of students who had negative ideas about the target culture is similar in both groups. Thus, it can be considered that they were nearly equal in terms of their attitudes about the target culture before the experiment.

\section{Question 2: Do you enjoy learning about English culture while learning English?}

In the experimental group, 10 out of 21 students did not like learning about English culture. In the control group, 7 out of 19 students did not enjoy learning English culture. Therefore, between the experimental and control groups, it is concluded that there is again a slight difference related to the percentages of the students' negative and positive answers. The comparison is shown in the table below:

Table 2. Pre-test scores of experimental and control groups for question 2

\begin{tabular}{llll}
\hline Group & $\mathbf{N}$ & Negative \% & Positive \% \\
\hline Experimental & 21 & 47.6 & 52.4 \\
Control & 19 & 36.8 & 63.2 \\
\hline
\end{tabular}

According to Table 2, 10 (47.6\%) out of 21 students in the experimental group and 7 (36.8 \%) out of 19 students in the control group did not enjoy learning English culture. This reveals that both groups were nearly equal in terms of their interests in the target culture before the experiment.

Question 3: Is it useful to learn English and Turkish cultures with the help of comparison?

In the experimental group, 10 out of 21 students thought that it was not useful to learn English and Turkish culture at the same time. Therefore, between the experimental and control groups, it has been figured out that there is not much difference related to the percentages of the students' negative and positive answers. The difference is shown in the following table: 
Table 3. Pre-test scores of experimental and control groups for question 3

\begin{tabular}{llll}
\hline Group & $\mathbf{N}$ & Negative \% & Positive \% \\
\hline Experimental & 21 & 47.6 & 52.4 \\
Control & 19 & 63.2 & 36.8 \\
\hline
\end{tabular}

According to Table 3, 10 (47.6\%) out of 21 students in the experimental group and 12 (63.2\%) out of 19 students in the control group thought that it was not useful to learn English and Turkish cultures at the same time. That is to say, most of the students in both groups were against learning the cultures with the help of comparison.

\subsection{The Analysis of Classroom Observation In-Study Procedure}

The data were gathered not only through pre-test and post-test but also through classroom observation. For this type of observation, video-camera recording and observation notes of the researcher were used. During the observation, every changing behaviour was recorded. The classroom observation was explained week by week. In the first week of the instruction, there were 19 students. While they were reading "Beowulf", it was marked that they were generally against English epic because they believed that the elements such as the monster-Grendel-, his supernatural mother, and the dragon in the epic were not real and not natural. Furthermore, the students were unwilling to deal with the epic. However, some of the students were interested in the epic. Moreover, they were happier than they were in the daily lessons. After reading "Beowulf" and answering the related questions, the students were expected to read "Basat and Tepegoz". The students were recorded more interested in this epic than they were in the previous one. They examined the pictures, read the epic and answered the questions willingly. Besides, it was observed that the students got surprised when they saw the similarities and differences between the two epics.

At the beginning of the study, the students were unwilling to deal with English epic because they found it was unreal. They had negative attitudes about the English epic, "Beowulf". However, they liked the Turkish epic much more. They also stated that they liked the English version of a Turkish epic. When they read the two epics, they immediately started to compare them. As they were making a comparison, they seemed to be more interested in the study. They were also recorded as they were enjoying the study. Besides, some of the students stated that they did not know that there were supernatural monsters in the Turkish epics. It may be asserted that the first week experiment was the same as it was expected to be. 
In the second week session, 18 students were exposed to study the similarities and differences of the epics read in the previous week. They studied the Venn diagram and found similar and different vocabulary in the epics. In this activity, the students easily remembered the themes and the vocabulary of the epics. They could easily find the common vocabulary used in both epics but they had a little difficulty in finding the differences between the epics. They generally enjoyed the activity, as it was not an ordinary and usual practice for them. Most of the students were eager to complete the diagram but few of them were not. Afterwards, the students were asked to complete the chart using the words they wrote in the Venn diagram. In this step, the students were supposed to write sentences related to the similarities and differences of the two epics. In this activity, the students had difficulty in writing sentences with the words in the Venn diagram. The instructor helped a lot in this step. However, the students did not like the activity. It was assumed that there were two reasons why the students did not like the activity. First, this kind of activity was above the level of the students. Secondly, the previous activity was about the same subject, so the students got bored.

Finally, the students were exposed to writing a dialogue about a given situation and acting it out. The aim of the role-play was to make the students study both cultures together. The characters of both epics were in the same dialogue. At the beginning of the activity, the students got excited about the characters. It was understood that this kind of activity was effective to increase the cultural awareness of the students. As they were not willing to write the dialogue, they were allowed to use some Turkish phrases and proverbs to make the dialogue enjoyable. They enjoyed the activity. They laughed a lot during the preparation and presentation. There were some reasons why they liked the activity. First, the main characters of English and Turkish epics were together. Moreover, they liked to act those characters and they could use Turkish phrases, as well.

In the third week of the instruction, 18 students were firstly expected to read the English epic "Paradise Lost". They were interested in the keywords and photographs. However, they had difficulty guessing the topic of the epic and guessing the correct order of the photographs. While reading the epic, it was recorded that they found the epic hard. They could not understand on their own, so the instructor helped them understand the text. Despite the difficulties, they enjoyed matching the paragraphs with the paragraph topics. In the last exercise, they were recorded that they easily found the true and false statements. Afterwards, the students read the Turkish epic "Altaic Creation Epic". They were amazed to see the keywords and photographs were 
similar. They easily guessed the topic of the epic and put the photographs in the correct order. They also easily match the paragraphs with the paragraph topics. They found the true and false statements with no difficulty, as well. It might be asserted that the students were more interested in this week's epics than the ones in the previous weeks. Their motivation was higher because the subject of the epics was interesting and enjoyable for them. Some of the students were recorded that they liked the English epic much more than the Turkish epic.

In the last week of the instruction, 16 students studied the Venn diagram as in the second week's experiment. They completed the diagram with the vocabulary both finding the similarities and differences between the epics of the previous week. The students easily completed the diagram finding out the common elements and different points of the epics. Compared to the differences, the students found the similarities much more easily. In the next step, the students tried to make sentences orally with the related vocabulary in the diagram. They became pleased since they were able to make meaningful sentences during the preparation. As the second activity, the students performed a role-play called "Here and There". They chose a situation, wrote a dialogue, and act it out in front of the class. Most of the pairs chose "Here". They stated that they liked to bring the characters back to the earth. Two pairs chose "There". During the preparation, all the students appeared to be enjoying the activity. They were impatient to read out the dialogues they wrote. It was fun to listen to the role-plays for both the students and the instructor. At the end of the activity, it was seen that all the students were happy with their work.

\subsection{Analysis of Pre-test and Post-test Scores of the Control Group After the Study}

Compared to the experimental group, no study was applied in the control group. The lessons continued as they were supposed to be under the school curriculum. While the experimental group was in an intense study with epics, the students in the control group were not performed anything special about the cultural issues. Foreign cultural information was transferred through the main course and reading books.

The students in this group were again asked three interview questions after four weeks. It has been concluded that there is a difference in pre-test and post-test answers of the students. Related to the first two questions, the negative answers increased. However, positive answers increased in the third question. The results are explained in the following: 


\section{Question 1: Is learning English culture necessary while learning English?}

Table 4.Pre-test and post-test scores of the control group for question 1

\begin{tabular}{llll}
\hline Control Group & $\mathbf{N}$ & Negative $\%$ & Positive $\%$ \\
\hline Pre-test & 19 & 31.6 & 68.4 \\
Post-test & 19 & 47.4 & 52.6 \\
\hline
\end{tabular}

In the pre-test, 6 out of 19 students were against the necessity of learning English culture while learning English. That is to say, 6 (31.6\%) out of 19 students believed that English culture was not necessary for learning English. After four weeks, 9(47.4\%) out of 19 students stated that learning English culture is not necessary for learning English. Table 4 has revealed a significant difference within the control group. In other words, the subjects in the control group changed their opinions related to the necessity of learning English culture. It can be seen that the number of students who have negative attitudes towards the target culture has increased. Three students changed their opinions. Moreover, the number of students who have positive attitudes related to the necessity of culture learning decreased.

\section{Question 2: Do you enjoy learning about English culture while learning English?}

Table 5. Pre-test and post-test scores of the control group for question 2

\begin{tabular}{llll}
\hline Control Group & $\mathbf{N}$ & Negative \% & Positive \% \\
\hline Pre-test & 19 & 36.8 & 63.2 \\
Post-test & 19 & 42.1 & 57.9 \\
\hline
\end{tabular}

In the pre-test, 7 (36.8 \%) out of 19 students did not enjoy learning English culture. After the four-week process, 8(42.1\%) out of 19 students began to think the same. According to Table 5, the number of negative opinions has slightly increased. Two students previously stated that they liked learning English culture, and then they began to think the opposite. However, one student previously stated that he/she did not like learning the culture but later he surprisingly declared that he liked it. The other students were thinking as in the pre-test. However, the number of positive attitudes decreased. 
Question 3: Is it useful to learn English and Turkish cultures with the help of comparison?

Table 6. Pre-test and post-test scores of the control group for question 3

\begin{tabular}{llll}
\hline Control Group & $\mathbf{N}$ & Negative \% & Positive \% \\
\hline Pre-test & 19 & 63.2 & 36.8 \\
Post-test & 19 & 47.4 & 52.6 \\
\hline
\end{tabular}

According to Table 6, in the pre-test, 12(63.2\%) out of 19 students thought that it was not useful to learn the two cultures at the same time with the help of comparison. However, in the post-test, the number decreased. 9 (47.4\%) out of 19 students thought that it was not useful. Three students changed their opinions and began to think that it was useful. Table 6 has also revealed that in the pre-test, while $36.8 \%$ of the students mentioned that it was useful to compare two cultures, in the post-test, the rate has increased to $52.6 \%$. In other words, 7 students in the pre-test and 10 students in the post-test believed that it was useful to learn the cultures at the same time with the help of comparison.

Considering all the differences between the pre-test and the post-test in the control group, it can be easily understood that the negative opinions of the students related to the target culture increased in a month. Thus, it may be asserted that the students were not glad to learn the target culture through the information transfer in the coursebook.

\subsection{Analysis of Pre-test and Post-test Scores of the Experimental Group After the} Study

After the study of epics in the experimental group, it was noted that there was a considerable change in terms of students' opinions in post-test. Here are the results of three questions in pre-test and post-test:

Question 1: Is learning English culture necessary while learning English?

Table 7. Pre-test and post-test scores of the experimental group for question 1

\begin{tabular}{llll}
\hline Experimental Group & N & Negative \% & Positive \% \\
\hline Pre-test & 21 & 42.9 & 57.1 \\
Post-test & 21 & 19.0 & 81.0 \\
\hline
\end{tabular}

In the pre-test, $9(42.9 \%)$ out of 21 students were against the necessity of learning English culture while learning English. However, in the post-test, 4(19.0\%) out of 21 students stated that learning English culture is not necessary for learning English. Table 7 has revealed a significant difference within the experimental group. In other 
words, most of the subjects in the experimental group changed their opinions related to the necessity of learning English culture. It can be seen that the number of students who have negative attitudes towards the target culture has decreased.

Unlike the pre-test, six students changed their opinions and gave positive answers to this question. The other three students still had the same idea. Surprisingly, one student gave a negative answer on the contrary to the pre-test. However, one student gave a positive answer in the pre-test but a negative answer in the post-test.

Question 2: Do you enjoy learning about English culture while learning English?

Table 8. Pre-test and post-test scores of the experimental group for question 2

\begin{tabular}{llll}
\hline Experimental Group & $\mathbf{N}$ & Negative \% & Positive \% \\
\hline Pre-test & 21 & 47.6 & 52.4 \\
Post-test & 21 & 33.3 & 66.7 \\
\hline
\end{tabular}

In the pre-test, $10(47.6 \%)$ out of 21 students did not enjoy learning English culture. After the four-week process, 7(33.3\%) out of 21 students began to think the same. Thus, three students changed their opinions. According to Table 8, the number of negative opinions again decreased. Three students previously stated that they did not like learning English culture, and then they began to think the opposite. The other students were thinking as in the pre-test.

Question 3: Is it useful to learn English and Turkish cultures with the help of comparison?

Table 9. Pre-test and post-test scores of the experimental group for question 3

\begin{tabular}{llll}
\hline Experimental Group & $\mathbf{N}$ & Negative \% & Positive \% \\
\hline Pre-test & 21 & 47.6 & 52.4 \\
Post-test & 21 & 23.8 & 76.2 \\
\hline
\end{tabular}

According to Table 9, in the pre-test, 10(47.6 \%) out of 21 students thought that it was not useful to learn the two cultures at the same time with the help of comparison. However, in the post-test, the number decreased. Only 5 (23.8 \%) out of 21 students thought that it was not useful. Six students changed their opinions and began to think that it was useful, and one student was previously thinking that it was useful but later he began to think the opposite. Table 9 has also revealed that in the pre-test, while 52.4 $\%$ of the students mentioned that it was useful to compare two cultures, in the posttest, the rate increased to $76.2 \%$. In other words, 11 students in the pre-test and 16 
students in the post-test believed that it was useful to learn the cultures at the same time with the help of comparison.

\subsection{Analysis of Post-test Scores of the Experimental Group and the Control Group} After the Study

Considering all the three questions in the questionnaire, it is clear that there is a significant difference between the experimental and the control groups related to the post-test scores. Here are the results of the post-test in both groups:

Question 1: Is learning English culture necessary while learning English?

Table 10. Post-test scores of the experimental and control groups for question 1

\begin{tabular}{llll}
\hline Post-test & N & Negative \% & Positive \% \\
\hline Experimental Group & 21 & 19.0 & 81.0 \\
Control Group & 19 & 47.4 & 52.6 \\
\hline
\end{tabular}

According to Table 10, the negative attitudes of the experimental group were calculated as $19 \%$, and the control group as $47.4 \%$. The positive ones of the experimental group were $81.0 \%$ and those of the control group were $52.6 \%$. This showed that the experimental group scored significantly higher than the control group in terms of positive attitudes.

Question 2: Do you enjoy learning about English culture while learning English?

Table 11. Post-test scores of the experimental and control groups for question 2

\begin{tabular}{llll}
\hline Post-test & N & Negative \% & Positive \% \\
\hline Experimental Group & 21 & 33.3 & 66.7 \\
Control Group & 19 & 42.1 & 57.9 \\
\hline
\end{tabular}

According to Table 11, the negative attitudes of the experimental group were calculated as $33.3 \%$, and the control group as $42.1 \%$. The positive ones of the experimental group were $66.7 \%$ and those of the control group were $57.9 \%$. This showed that the experimental group scored higher than the control group in terms of positive attitudes. 
Question 3: Is it useful to learn English and Turkish cultures with the help of comparison?

Table 12. Post-test scores of the experimental and control groups for question 3

\begin{tabular}{llll}
\hline Post-test & N & Negative \% & Positive \% \\
\hline Experimental Group & 21 & 23.8 & 76.2 \\
Control Group & 19 & 47.4 & 52.6 \\
\hline
\end{tabular}

According to Table 12, the negative attitudes of the experimental group were calculated as $23.8 \%$, and the control group as $47.4 \%$. The positive ones of the experimental group were $76.2 \%$ and those of the control group were $52.6 \%$. This showed that the experimental group scored significantly higher than the control group in terms of positive attitudes.

\subsection{Lesson Diary After the Study}

Taking the results of the post-test in the experimental group, a lesson diary was applied to see the opinions of the students related to the study. The aim was to get information about their likes, dislikes and difficulties with the procedure. It was also aimed to see what they learnt about the target culture. It was prepared in students' native language to make them feel relaxed and comfortable for their answers. Taking the opinions of the students in the experimental group, it was concluded that there were a lot of common comments of the students. Here are the important common results given in the table below:

\begin{tabular}{|l|l|}
\hline $\begin{array}{l}\text { I have learnt the following: } \\
\text { 4(19\%) out of 21students have learnt that there are different } \\
\text { cultures and points of view. }\end{array}$ & $\begin{array}{l}\text { Result } \\
\text { More than half of the students seem to } \\
\text { have intercultural awareness. Some of } \\
\text { them also mentioned the epics they } \\
\text { has its own culture but there are similarities between them, } \\
\text { as well. Cultures can affect each other. } \\
\begin{array}{l}5(23.8 \%) \text { out of } 21 \text { students have learnt the epics they have } \\
\text { just read and they have also learnt the importance of reading } \\
\text { them. }\end{array}\end{array}$ \\
$\begin{array}{l}1(4.7 \%) \text { out of } 21 \text { students has learnt about history. } \\
\text { learnt anportance of them. }\end{array}$ & \\
\hline
\end{tabular}




\section{I had difficulty in understanding the following:}

$4(19 \%)$ out of 21 students had difficulty in matching the paragraphs with the paragraph topics and pictures.

$2(9.5 \%)$ out of 21 students had difficulty in writing the dialogues.

$4(19 \%)$ out of 21 students had difficulty in comparing the two different cultures.

$5(23.8 \%)$ out of 21 students had difficulty in understanding the reading texts.

$3(14.3 \%)$ out of 21 students had difficulty in monsters and supernatural elements in the epics.

$1(4.8 \%)$ out of 21 students had difficulty in understanding why this kind of study started so late and lasted for a little time.

1 (4.8\%) out of 21 students had difficulty in understanding which epic is real and which one is not.

$1(4.8 \%)$ out of 21 students had difficulty in understanding English itself.

I have liked the following:

$5(23.8 \%)$ out of 21 students have liked the comparison of the two cultures in terms of epics.

$6(28.6 \%)$ out of 21 students have liked the epics.

$5(23.8 \%)$ out of 21 students have liked that the lessons have become enjoyable and different.

$3(14.3 \%)$ out of 21 students have liked writing the dialogues.

$3(14.3 \%)$ out of 21 students have liked the new vocabulary.

$1(4.8 \%)$ out of 21 students has liked the pictures.

\section{I have not liked the following:}

$9(42.9 \%)$ out of 21 students stated that there was nothing they did not like and everything was very enjoyable and useful.

$5(23.8 \%)$ out of 21 students have not liked that the epics are supernatural and ridiculous.

\section{Result}

Most of the students seem to have difficulty in performing skills in the second language. A few of the students have difficulty in comparison to the cultures.

\section{Result}

Most of the students seem to have enjoyed this kind of instruction. They like the comparison of the cultures via epis.

\section{Result}

Nearly half of the students seem to have nothing negative about the instruction. Few of them seem to have preferred the epics would be real. Few of the students have already difficulty in dealing with the second language skills, such as reading and 
$1(4.8 \%)$ out of 21 students has not liked to learn the English epics.

$1(4.8 \%)$ out of 21 students has not liked that the epics are hard to understand.

$1(4.8 \%)$ out of 21 students has not liked to act out the dialogues in front of the class.

$1(4.8 \%)$ out of 21 students has not liked to read the epics in English.

$1(4.8 \%)$ out of 21 students has not liked to bring the worksheets regularly.

$1(4.8 \%)$ out of 21 students has not liked that the lessons have been recorded by a video camera.

$1(4.8 \%)$ out of 21 students has not liked to have difficulty in learning some parts of the epics that are opposite to our religion. acting out. The others seem to have other negative opinions about the instruction such as video recording, taking the worksheets every day and some points that are opposite our religion.

\section{Conclusion and Suggestion}

This study was conducted to determine whether epics influence the intercultural awareness of second language learners at SOFL. The experimental group including 21 students was taught selected 2 English and 2 Turkish epics. Related activities were performed. This procedure was not performed in the control group of 19 students. The lessons here continued according to the curriculum. The students learned about the target culture as information transfer from the coursebook. Both groups were given a questionnaire as a pre-test and a post-test. The semi-structured questionnaire including three open-ended questions was about the attitudes of students towards the target culture. The results showed a significant difference in the mean gains of the samples. Using epics in teaching the target culture proved to be more effective for intercultural awareness of second language learners than information transfer from the books.

The results of the study implicate that a student's intercultural awareness necessitates an emphasis on literature. Students need many opportunities for using literature in class since they do not enjoy learning about the target culture as the information transfer. Furthermore, they find this irritating and then, they become unwilling to learn about the target culture. However, when they learn about literature, especially comparing the target culture and their own one, they become to enjoy the lessons and be willing to learn. For this purpose, epics can be one of the best means of literature. 
While teaching the culture, teachers will see that information transfer is not enough for students' intercultural awareness. As recent studies demonstrate, extracurricular cultural activities are suggested as a solution to raise students' awareness and interest in other cultures. In that case, epics will be a suitable source for them as they not only reflect the cultures but also have something in common. Apart from epics, teachers should allocate time for regular use of other literary works such as legends, poems, fairy tales and short stories during class. Showing pictures, videos, sharing experiences with students and encouraging them to be more involved in other cultures might be the solutions for an effective language teaching process. Additionally, teachers should start with short periods and gradually increase the use of materials and should provide opportunities to share information that is interesting, humorous, dramatic or unknown.

One of the implications of this study is, the results of a larger-scale study will be more reliable due to the smallness of the sample size in the study. What is more, as the study carried out in a prep class at a foreign language school, there were some limitations related to the intercultural activities. The students who could not pass the proficiency exam at the beginning of the year had to deal with a new language and a lot of exams during the year. However, their level of English was not enough to understand the epics and perform the related activities. For that reason, the study was hard for both the students and the researcher. Thus, the use of literature systematically for students' intercultural awareness in class should start as a part of the curriculum from the beginning of one's education and must be applied during all the English lessons. Students will be able to recognize and develop their awareness through the comparison of two cultures. Therefore, contrastive analysis in teaching culture should be encouraged.

In conclusion, before helping students with their intercultural awareness during the language learning process, teachers should be trained with the necessary techniques to apply related activities in the classes. In this way, the students will easily be more competent in second language learning. However, there are some challenges English language teachers have experienced in the intercultural teaching process. Syllabus or curriculum is the most evident reason that prevented teachers from being flexible and doing extra cultural activities or giving more information about them in the classrooms. Studies indicate that teachers need to follow the syllabus or curriculum, which gives them almost no time to do any extra intercultural activity. That is why the teachers first should use the intercultural activities following the curriculum. Besides 
the language transfer activities in the coursebooks, there should be a good deal of cultural activities in the classroom context. This kind of teaching and learning would certainly be more enjoyable and realistic. Although the studies carried out in Turkey has some limitations, their numbers are hopefully are getting more and more.

\section{References}

Başbay, A., \& Bektaş, Y. (2009).Çokkültürlülük bağlamında öğretim ortamı ve öğretmen yeterlikleri. Eğitim ve Bilim, $34 \quad$ (152), 31-42. http://egitimvebilim.ted.org.tr/index.php/EB/article/view/6

Brumfit, C.J., \& Carter, R. A. (2000). Literature and Language Teaching. Oxford University Press.

Byram, M. (1990). Foreign language teaching and young people's perceptions of other cultures. Modern English Publications and the British Council.

Byram, M., \& Flemming, M. (1998). Language Learning from an Intercultural Perspective. Cambridge University Press.

Carter, R.A., \& Long, M.N. (1991). Teaching Literature. Longman Press.

Collie, J., \& Slater, S. (1996). Literature in the Language Classroom. Cambridge University Press.

Corbett, J. (2003). Languages for Intercultural Communication and Education, 7: Intercultural Approach to English Language Teaching. Multilingual Matters Limited.

Derman-Sparks, L. (1993/94). Empowering children to create a caring culture in a world of differences. Childhood Education, 70(2), 66-71. https://doi.org/10.1080/00094056.1993.10520994

Donahue, M., \& Parsons, A. H. (1982). The use of role-play to overcome cultural fatigue. TESOL Quarterly, 16, 359-365. https://doi.org/10.2307/3586635

Douglas, B. H. (1994). Principles of language learning and teaching. Englewood Cliffs.

Elçin, Ş. (1997). Halk Edebiyatı Araştırmaları (Research on Folk Literature).Culture Ministry Publication.

Fantini, A.E. (1997). New ways in teaching culture. TESOL Series II 2(2). TESOL.

Ghosn, I. K. (2002). Four good reasons to use literature in the primary school ELT. ELT Journal, 56(2), 172-179. https://doi.org/10.1093/elt/56.2.172

Kachru, B. (1986). Non-native literatures in English as a resource for language 
teaching. In C. Brumfit and R. Carter (Ed.), Literature and language teaching. Oxford University Press.

Kan, A. T. (2006). Promoting cross-cultural understanding in a foreign language class by using Mevlana's stories. Mevlana Symposium.

Kaplan, M. (1958). Oğuz Kaan Destanı ile Dede Korkut kitabında eşya ve aletler. TTK Basimi.

Kodotchigova, M. A. (2002). Role play in teaching culture: Six quick steps for classroom implementation. The Internet TESOL Journal, 8(7). http://iteslj.org/Techniques/Kodotchigova-Role- Play.html

McKay, S. L. (2000). Teaching English as an international language: Implications for cultural materials in the classroom. TESOL Journal, 9(4), 7-11. https://doi.org/10.1002/j.1949-3533.2000.tb00276.x

Onalan, O. (2005). EFL teachers' perceptions of the place of culture in ELT: A survey study at four universities in Ankara/Turkey. Journal of Language and Linguistic Studies 1, 215-235. https://www.jlls.org/index.php/jlls/article/view/17/19

Özışık, B. Z., Yeşilyurt, S., \& Demiröz, H. (2019). Developing intercultural awareness in language teaching: Insights from EFL lecturers in Turkey. Journal of Language and Linguistic Studies, 15(4), 1436-1458. https://doi.org/10.17263/jlls.668546

Pedersen, P. (1936). A handbook for developing multicultural awareness. American Association for Counseling and Development.

Reinhold, W. (2002). Teaching India in the EFL-Classroom: A Cultural or an Intercultural Approach in Byram, Michael (Ed.) Languages for Intercultural Communication and Education, 6: Context and Culture in Language Teaching and Learning. Multilingual Matters Limited.

Rollin, R. (1989). On redefining literature, In Şahin, M. Teaching literature with emphasis of poetry. MA Thesis.

Stuart. G., \& Nocon, H. (1996). Second culture acquisition: Ethnography in the foreign language Classroom. The Modern Language Journal, 80(4), 431-449. https://doi.org/10.1111/j.1540-4781.1996.tb05463.x

Sahin, I. (2005). The effect of native speaker teachers of English on the attitudes and achievement of learners. Journal of Language and Linguistic Studies 1, 29-42. https://www.jlls.org/index.php/jlls/article/view/4 
Taflı, H. (2006). The Alp and the Monster in Pre-islamic The Book of Dede Korkut and Beowulf. MA Theses. Niğde.

Tosuncuoglu, I. (2019). Intercultural Communicative Competence Awareness of Turkish Students and Instructors at University Level. International Journal of Higher Education, 8(1), 44-54. https://doi.org/10.5430/ijhe.v8n1p44

Tural, S. (1999). Sensibility flowing from history to epic. AKM Publishing.

Tutal, Nilgün. 2006. Küreselleşme iletişim kültürlerarasılık. Kırmızı Yayınları.

Yilmaz, B., \& Özkan, Y. (2015). The perspectives of English language teachers on intercultural awareness at a university prep-school in Turkey. Mobile-assisted ESP learning in technical education, 3(3), 258.

Zorba, M. G., \& Çakir, A. (2019). A Case Study on Intercultural Awareness of Lower Secondary School Students in Turkey, Novitas-ROYAL (Research on Youth and Language), 13(1), 62-83. https://eric.ed.gov/?id=EJ1214200 


\section{APPENDICES}

\section{Appendix I}

Sevgili Öğrenciler,

Selçuk Üniversitesi Eğ̈im Fakültesi İngilizce Öğretmenlï̆i Bölümü̈nde yüksek lisans yapmaktayım. Bu, öğrencilerin dil öğreniminde, kültürler arası bilince destanların etkileri konulu bir yüksek lisans tezidir. Bu yüzden yabancı dilin kültürü konusunda belirteceğiniz görüşleriniz tezimin konusuyla doğrudan ilgilidir. Bu ankette yer alacak düşünceleriniz kesinlikle gizli kalacak, sadece tez çalışmam için kullanılacaktır. Sorulara samimi ve dürüst olarak cevap vermeniz çok önemlidir. Lütfen bütün sorulara cevap veriniz. Zaman ayırıp anket çalışmasında yer alarak bana yardım ettiğiniz için çok teşekkür ederim.

Nuriye Külahlı Selçuk Üniversitesi

Yabancı Diller Yüksekokulu

2008

İNGILLIZCE ÖĞRENIMINDE KÜLTÜRÜN ROLÜ KONUSUNDA ÖĞRENCILERIN GÖRÜŞLERI

1.İngilizce öğrenirken, İngiliz kültürünü de öğrenmek gerekli midir? Lütfen açıklayınız.

2.İngilizce öğrenirken, İngiliz kültürü ile ilgili bilgileri öğrenmekten hoşlanıyor musunuz? Lütfen açklayınız.

3.İngiliz kültürü ile Türk kültürünü karşılaştırmalı öğrenmek, dil öğreniminde yararlı olur mu? Lütfen açıklayınız.

Appendix II

OLD ENGLISH EPIC BEOWULF

1. Look at the pictures and key words below, and then guess what the epic

Key Words: armour, supernatural, cave, treasure, dragon, monster, sword, knight, fatal wound.

2. Look at the pictures, and then guess the correct order of the epic.

3. Read the epic "Beowulf". Were you right about the order?

4. Read the epic again and match the paragraphs with the paragraph topics in the following:

a) Beowulf and Grendel's mother ( ) b) Beowulf and the dragon ( )

c) Beowulf and Grendel $\quad\left(\begin{array}{ll}\text { ) } & \text { d) The danger of Grendel ( ) }\end{array}\right.$

5. Read the epic again and answer these questions.

1. Why did Beowulf go to Denmark? 2. Where did Grendel and his mother live?

3. How did Beowulf kill Grendel and his mother? 4. What did the King of Denmark give Beowulf?

5. Why did not the knights fight the dragon? 6. Why did Beowulf put on his armour again?
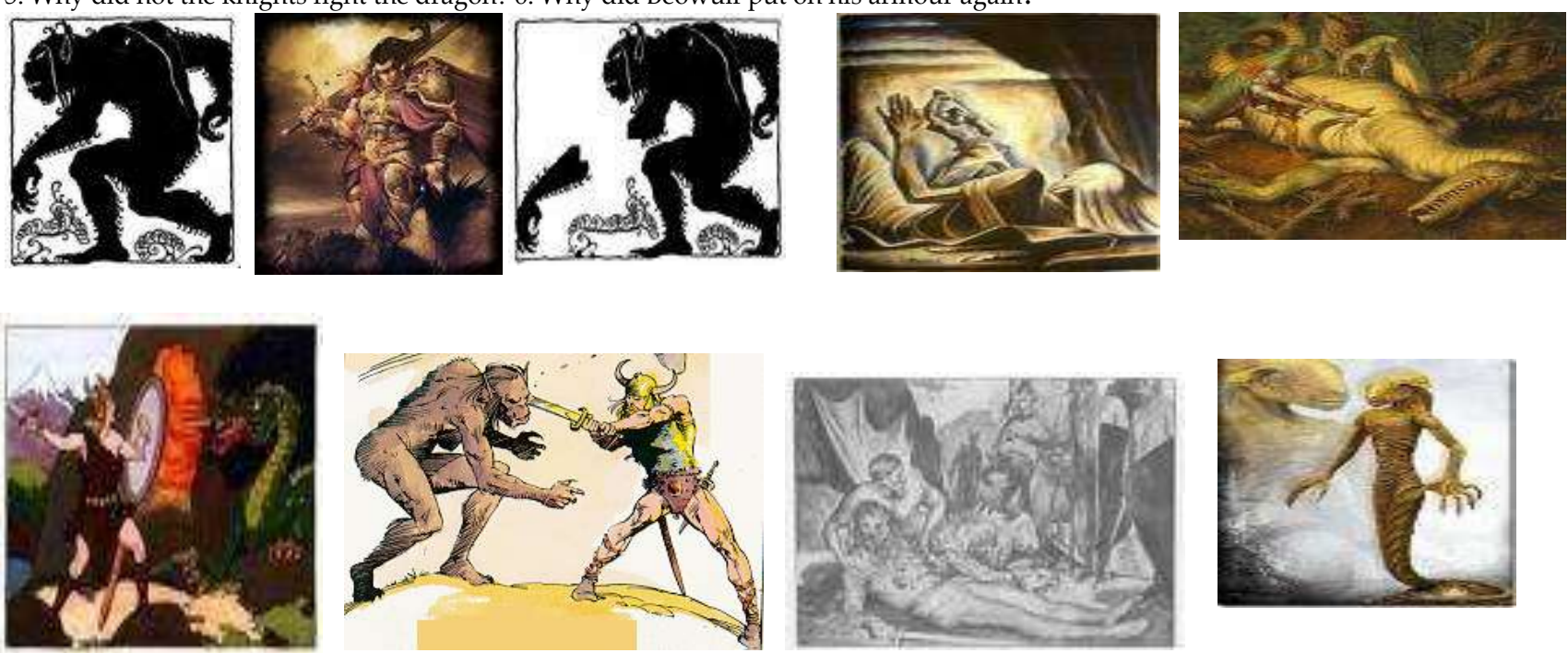

\section{BEOWULF}

(1) Once upon a time, there was a horrible monster called Grendel. He was half man half monster. He lived in Denmark. One day, he went to the king's castle. The king and his men tried to kill the monster but their swords were useless. A knight called Beowulf heard about the problem and went to Denmark to help the king.

(2) That night, Beowulf and his men took off their armour and put away their swords and went to sleep. The monster came into the castle and killed a knight. Beowulf woke up and fought the monster- he pulled off an arm! Grendel went back to his home in a lake and died.

(3) Grendel's supernatural mother was very angry and the next night she went to the castle and killed a knight. In the morning, Beowulf went to the lake. He killed Grendel's mother with a special sword. When he came back, the king was very happy and gave Beowulf presents and money.

(4) Beowulf went back to his country and became a king. He was king for fifty years. However, one day, a dragon came to his country, and it attacked people. It lived in a cave with treasure. The dragon was very big and breathed fire. The knights were afraid and they did not want to fight the dragon. King Beowulf was an old man but he put on his armour again and went to the dragon's cave with his men. At the end of the fight, Beowulf killed the dragon but he got a fatal wound and died. 


\section{THE BOOK of DEDE KORKUT BASAT and TEPEGOZ}

1. Look at the pictures and key words below and then guess what the epic is about Key words: ring, cave, treasure, monster, supernatural, arrow, sword, victory, invulnerability, defeat 2. Look at the pictures, and then guess the correct order of the epic.

3. Read the epic "Basat and Tepegoz". Were you right about the order?

4. Read the epic again and match the paragraphs with the paragraph topics in the following:

a) The death of Tepegoz ( ) $\quad$ b) The destruction and bargain of Tepegoz ( )

c) How Tepegoz became a monster ( ) d) Plead for help ( )

5. Read the epic again and answer these questions.

1. Why did Aruz Koca dismiss Tepegoz from the Oguz tribe? 2. Where did Tepegoz start to live then?

3. Why could not Oguz Turks defeat Tepegoz? 4. Why did Basat want to kill Tepegoz?

5. How did Basat kill Tepegoz?
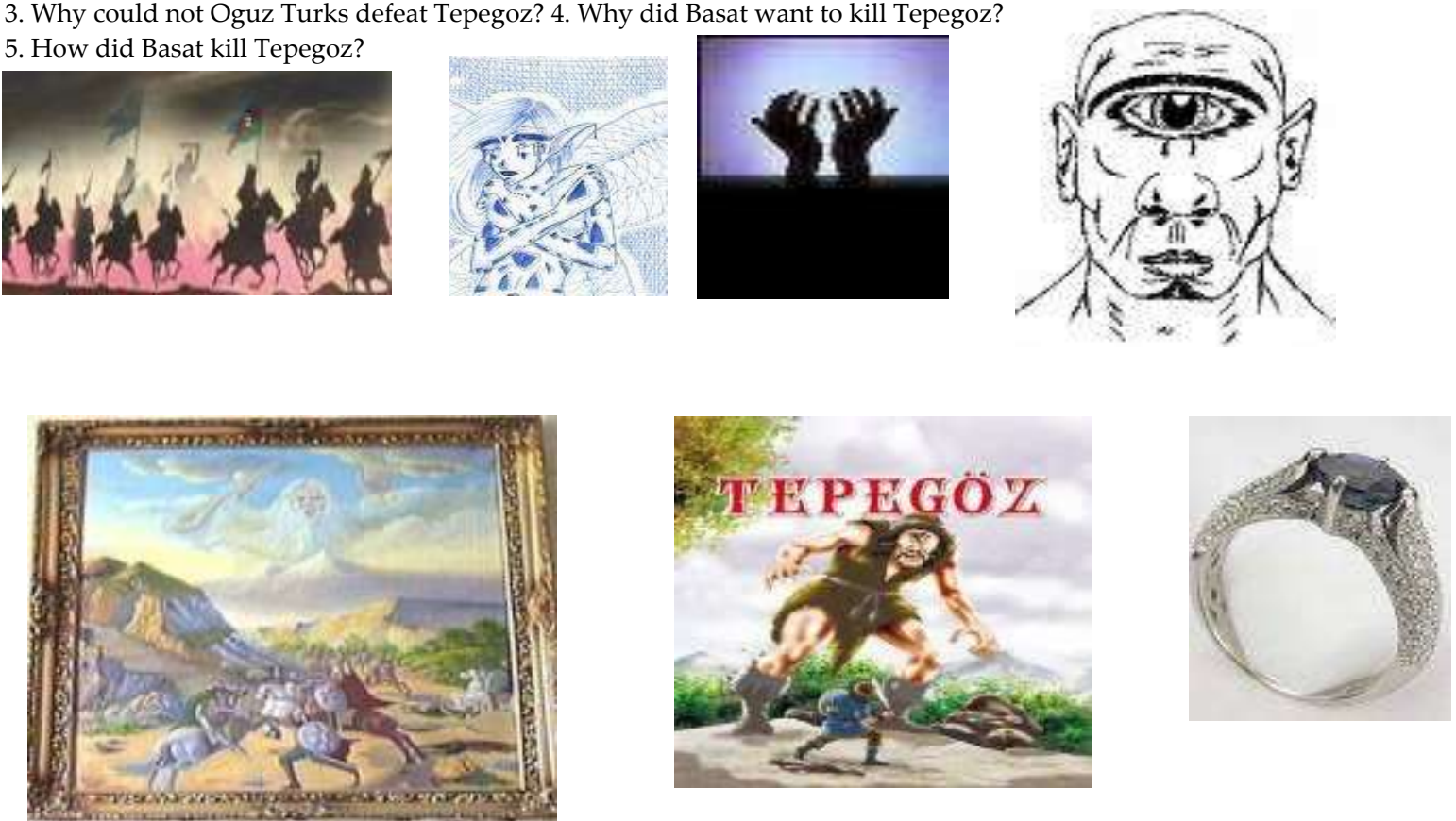

BASAT AND TEPEGOZ

(1) Once upon a time, there was a horrible monster called Tepegoz, a giant with one eye. His mother was a fairy woman and his father was a shepherd of Aruz Koca. He was grown up in Oguz tribe. The Oguz Turks fed it and looked after it. Tepegoz was playing with the children. Meanwhile, it began to eat their ears. Aruz Koca got angry and told it to go away. The supernatural mother of Tepegoz got very angry and gave him an invulnerability ring to protect him against everything. Tepegoz began to live in a cave called "Salahane" with treasure.

(2) The Oguz Turks put away their swords and arrows and fought against Tepegoz. However, it was useless. He began to eat Oguz people. He killed 60 men. He defeated the great heroes of the Oguz, and Dede Korkut was called to stop the danger of Tepegoz. Dede Korkut went to its cave to talk. Tepegoz wanted 60 men to eat a day. At the end of the conversation, two serving men plus a daily feed of two men and five hundred sheep were given to Tepegoz.

(3) The situation was better but still two men were daily eaten by Tepegoz. Oguz people, especially mothers, were sad. One day, one of the sad mothers went to the tent of a warrior named Basat who just returned from a battle. The mother pleaded for her son, and informed Basat that Tepegoz also killed Basat's brother, Kiyan Seljuk.

(4) Basat decided to kill Tepegoz but his mother and other Oguz Khans did not want Basat to do it. At the end, Basat fought with Tepegoz and with the strength of God defeated him, wounding him in the eye, and then cutting off his head with the sword of Tepegoz. Dede Korkut prayed for him for the victory. 


\section{Appendix III}

Similarities and Differences

Between Beowulf and Basatd Tepegöz

1. Work in groups and complete the Venn Diagram with the similarities and differences between "Beowulf" and "Basat \& Tepegöz" just using the words.

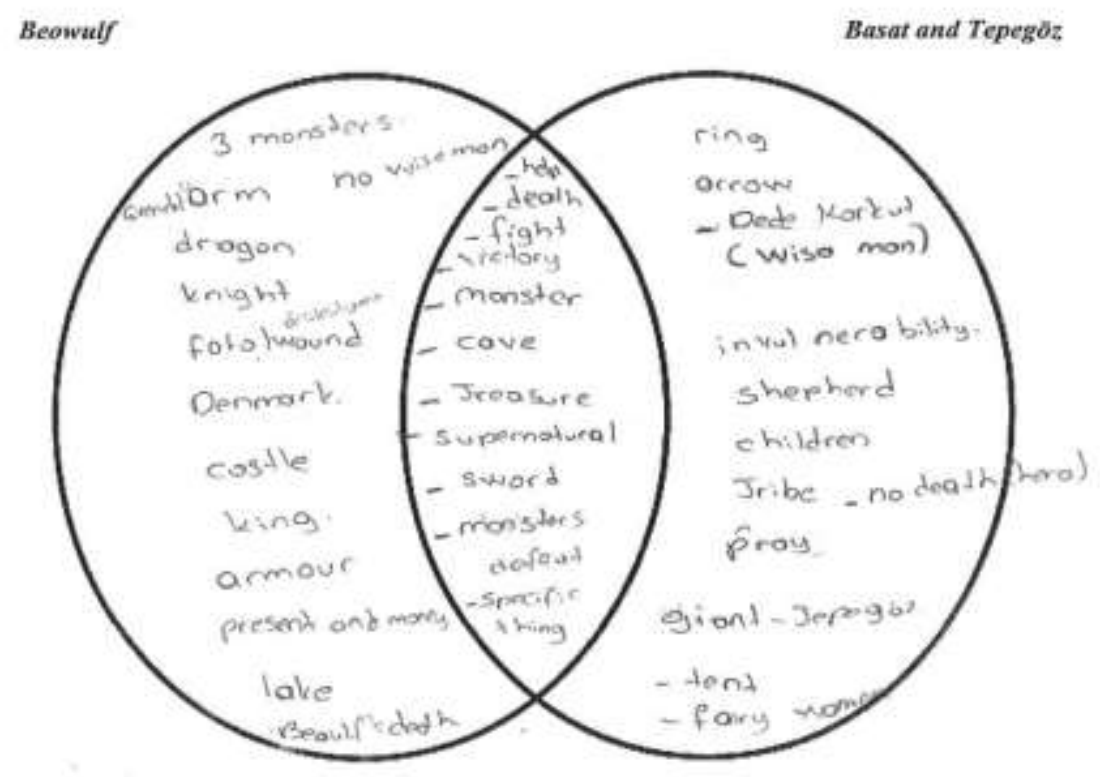




\section{Appendix IV}

2. Use the words above and complete the following table writing the similarities and differences between the epies.

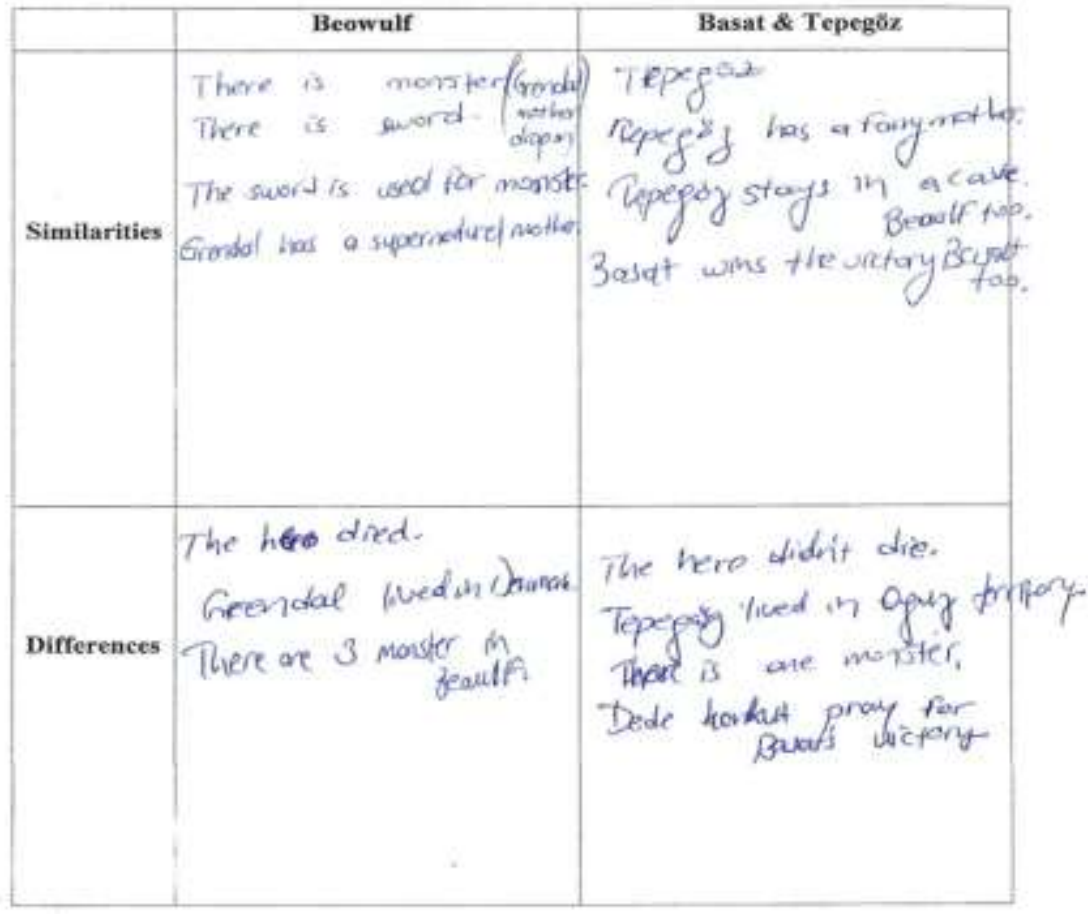




\section{Appendix V}

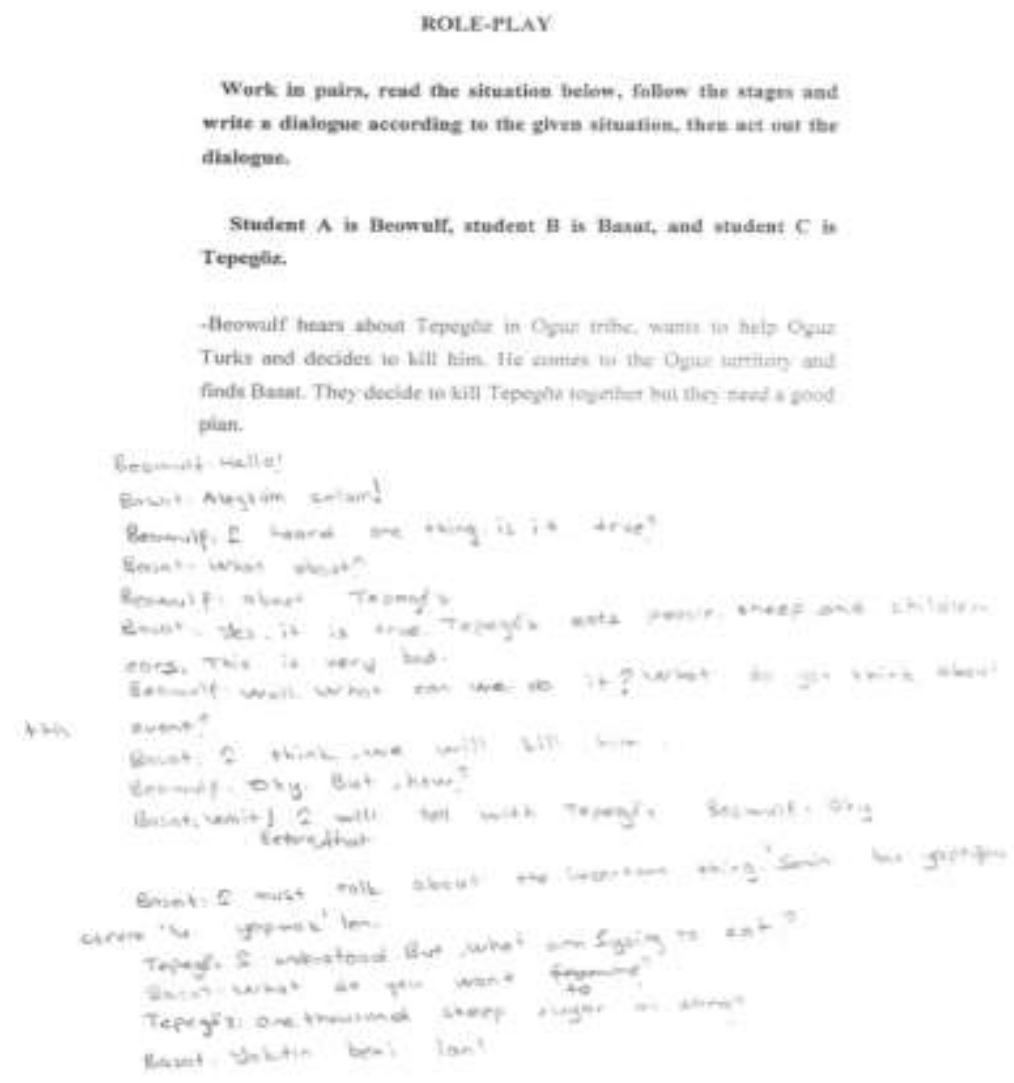




\section{Appendix VI}

\section{PARADISE LOST}

1. Look at the pictures and key words below, and then guess what the epic is about.

Key Words: disobedient, angel, Hell, forbidden, naked, punishment, painful, apologize, sacrifice, evil, expel.

2. Look at the pictures, and then guess the correct order of the epic.

3. Read the epic "Paradise Lost". Were you right about the order?

4. Read the epic again and match the paragraphs with the paragraph topics below. Punishment () Adam and Eve's Leaving the Paradise ( )
Satan's Terrible Plan ( ) Eating the Forbidden Fruit ( )

5. Read the epic again and write $\mathrm{T}$ if the statement is true, write $\mathrm{F}$ if the statement is false.

1. Satan decided to fight against the mankind. ()

2. God warned Adam and Eve about Satan. ( )

3. Eve did not want to eat the forbidden fruit but Adam did. ( )

4. Satan was punished but Adam and Eve were not. ( )

5. Adam and Eve were grateful to the Son for his sacrifice. ( )
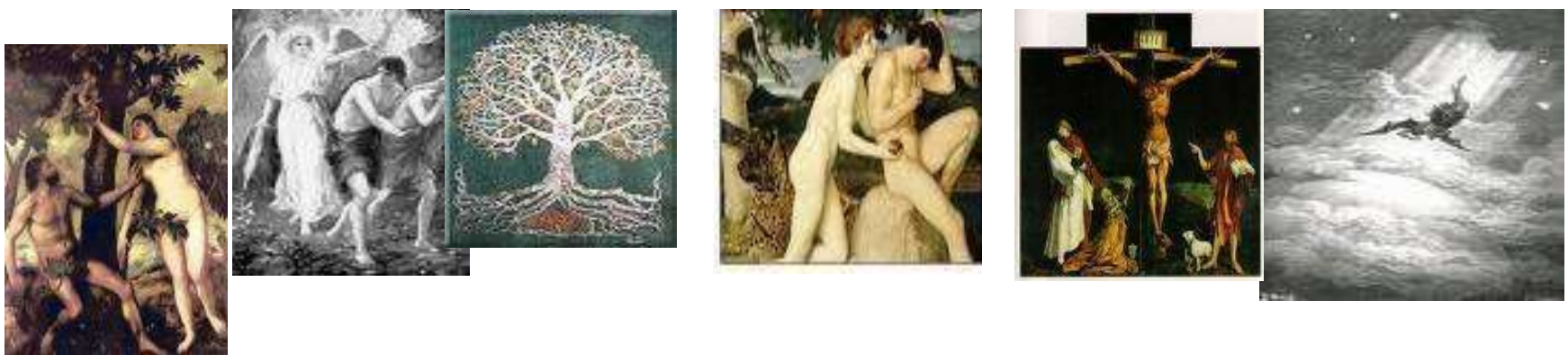

\section{PARADISE LOST}

(1) Satan and his army of angels were lying in the burning lake. They were disobedient to God so they were sent to Hellcalled Chaos or Darkness. They built a terrible palace called Pandemonium. They planned a battle against humanity and Satan started his journey. He flew to earth but God saw Satan flying. Satan came to the earth as a handsome angel. Uriel, who was guarding the earth, let him enter the earth and see the creation of God. However, Gabriel, who was guarding the gate of Paradise, saw Satan in the Garden of Eden while he was whispering in the ear of Eve as she was sleeping. Gabriel dismissed Satan from the Eden.

(2) God sent Raphael to warn Adam and Eve. Raphael explained what Satan did and how he fell from the Paradise. The next morning, while Eve was working in the garden alone, Satan came as a snake. He started to talk about her beauty. He also showed her the Tree of Knowledge. It was a forbidden fruit. God did not let them eat the fruit of it. However, Eve ate the forbidden fruit and decided to share it with Adam. Adam agreed to eat the fruit because he did not want to leave Eve. After eating the fruit, they fell asleep. When they woke up, they were naked so they immediately covered themselves with leaves.

(3) As Adam and Eve ate the forbidden fruit, God sent his Son to judge them. Eve was punished with painful childbirths and submission to her husband. Adam was punished with a painful battle with nature and hard work. Satan returned to hell in victory. However, all the angels in the hell became ugly monsters and reptiles. Satan became a horrible snake, as well. It was his punishment.

(4) Adam and Eve apologized to God and with his Son's wish God decided to send his Son to earth to sacrifice himself against the evil Trinity- Sin, Death and Satan. God sent Michael to expel Adam and Eve from the Paradise. He explained the possible future of humanity until Son came down to earth. Adam and Eve were thankful that the Son sacrifice and Adam held Eve's hand as they were leaving the Garden of Eden.

In the second lesson, the students were asked to read "Altaic Creation Epic". Here, our aim was to increase the intercultural awareness of the students. The activities applied in the first lesson were performed as in the following

\section{ALTAIC CREATION EPIC}

1. Look at the pictures and key words below, and then guess what the epic is about.

Key Words: disobedient, induce, punishment, forbidden, dismiss, painful.

2. Look at the pictures, and then guess the correct order of the epic.

3. Read the epic "Altaic Creation Epic". Were you right about the order?

4. Read the epic again and match the paragraphs with the paragraph topics

( ) Eating the forbidden fruit ( ) Tree of Humanity

( ) Disobedience of Er-kishi ( ) Leaving the Heaven ( ) Punishment

5. Read the epic again and write $\mathrm{T}$ if the statement is true, write $\mathrm{F}$ if the statement is false.

1. God Kara-han created Er-kishi because he was alone. ( )

2. God Kara-han did not give Er-kishi the people he wanted. ( ) 
3. Nobody was interested in Er-kishi. ( )

4. Doganay wanted to eat the forbidden fruit, as well. ( )

5. God gave punishments to all the creatures in the Heaven. ( )
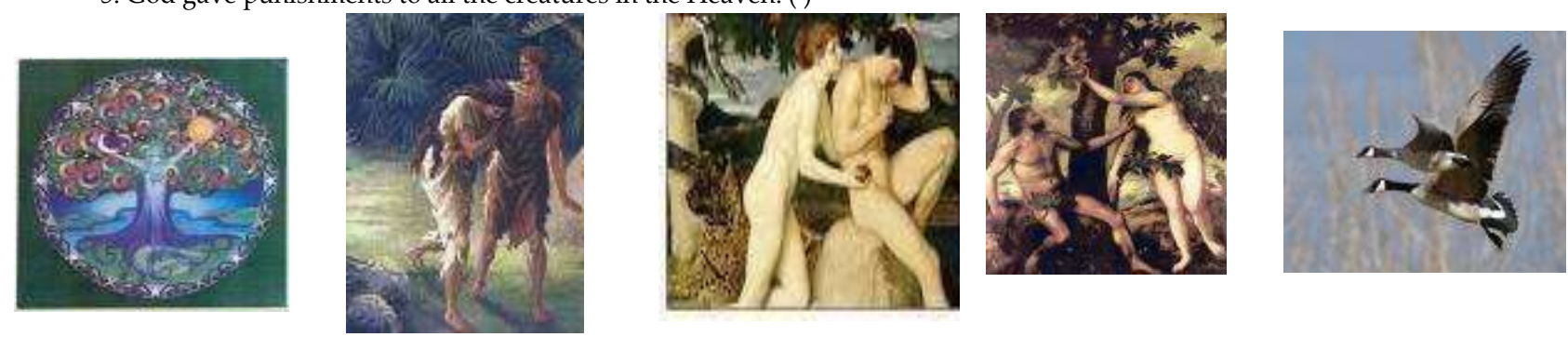

\section{ALTAIC CREATION EPIC}

1. There was no noise, no breathe, only water. In this loneliness, God Kara-han was flying in the shape of a white goose, he felt himself alone. Suddenly, someone called his name from the water. That was Ak-ana. She appeared with a fascinating beauty. Akana suggested him to create. Then, Kara-han created Er- kishi. They started to fly together, God Kara-han was above, Er-kishi was below. They became closest friends. However, Er-kishi wondered why he was flying below, and why they are not equal. While he was thinking about the answers, he fell into the water and splashed Kara-han. He began to think that he was stronger than Kara-han were, he made Kara-han wet. However, God knew his intention; Er-kishi became disobedient to God. Thus, God Karahan decided to send Er-kishi under water, into the darkness.

2. As Er-kishi was in the darkness, there was a tree growing above the earth. It was dry so Kara-han created branches, leaves and birds. There were nine branches. However, it was still dry. God Kara-han created nine people in the roots of the branches. The woman between the south and the north went to the man in the south, she was very attractive.

3. Kara-han called Er-kishi to see his creation. Er-kishi was shocked to see the new creation and he wanted some of the people but Kara-han did not let him take the people. He only let Er-kishi the people he could induce. Er-kishi became happy because this was not a punishment. However, Kara-han created snake and dog to guard the people. Er-kishi met the people and talked about the forbidden fruit in the garden. No one except the woman in the south was interested in Er-kishi. The name of the woman was Ece and man was Doganay. They were a happy couple. After a while, Er-kishi came again while everybody was sleeping. Ece and Doganay were not sleeping. Er-kishi began to talk to Ece in the shape of snake. Unfortunately, he gave her the fruit, Doganay begged her not to eat it but it was too late!... She put half of the fruit into Doganay's mouth.

4. Everybody woke up and saw them. All the creatures began to wait for their punishment. God Kara-han came and asked questions to the snake, the dog, Ece, Doganay, and Er-kishi. He dismissed them from the Heaven to the earth. Doganay's punishment was hard work to feed his family, Ece's punishment was painful childbirths and old and tired body, the snake would be the enemy of the human and the dog was not the man's best friend any more.

5. Finally, Er-kishi would be like this forever, and the people who believed him would be evil, too. As they were leaving the Heaven, God Kara-han wanted the people to call him "Ulgen", and the name of Er-kishi became "Erlik". He warned the people against Erlik on the earth. 


\section{Appendix VII}

\section{Similarities and Differences}

Between Paradise Lost and Altaic Creation Epic

1. Work in groups and complete the Venn diagram with the similarities and differences between "Paradise Lost" and "Altaic Creation Epie" just using the words.

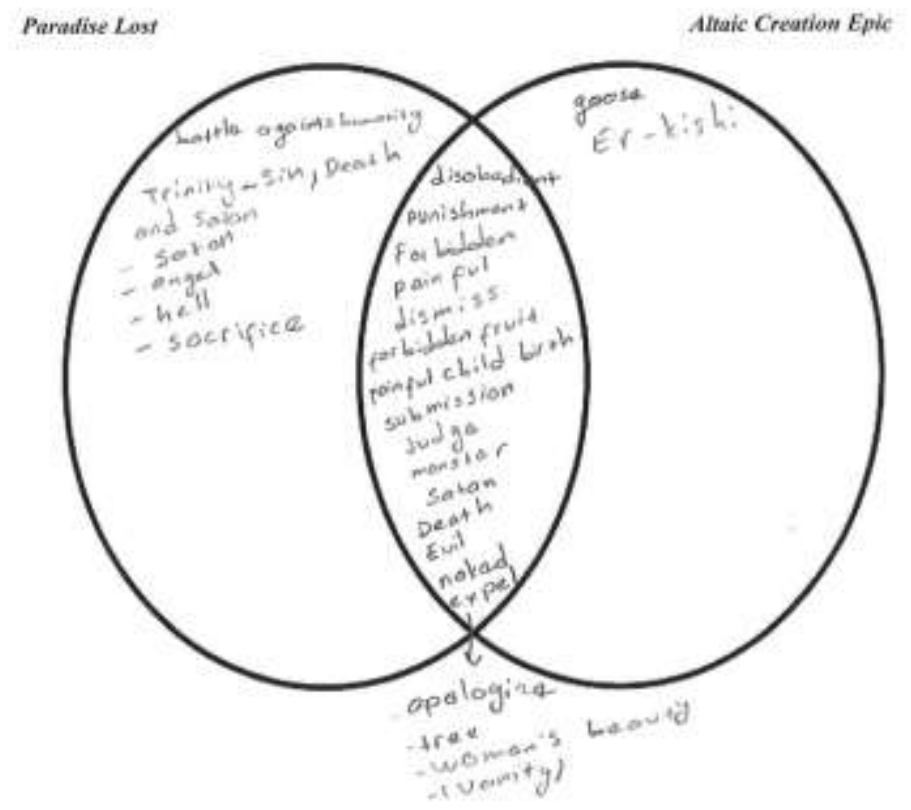




\section{Appendix VIII}

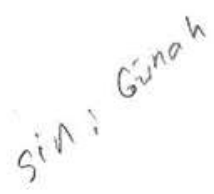

\section{ROLE-PLAY}

\section{HERE \& THERE}

Work in pairs; choose one of the situations below. Write a dialogue according to the given situation, and then act out the dialogue.

\section{HERE}

1. Adam and Eve is a happy couple but they are very poor. They always dream about being rich. One day, Eve makes a decision and explains it to Adam. The plan is to rob a bank and be rich. Adam knows that it is a terrible idea but he also knows that he cannot live without her. He cannot decide what to do but he has to make a decision.

\section{THERE}

2. Ece and Doganay is a happy couple in the Paradise. Ece wants to eat the forbidden fruit but Doganay knows that it is wrong. He also knows that he cannot persuade her and loves her so much .

$$
\begin{aligned}
& \text { Eca: Doganay I would like to eat the forbiddenfruit } \\
& \text { Doganay: You dort talk about the forbidder frwit int he } \\
& \text { I have different good idaa. Lat's go in the town and } \\
& \begin{array}{l}
\text { we biy variaty pruit in shotping. } \\
\text { Ece: No. Doganay. But I want to eat the forbid den }
\end{array} \\
& \begin{array}{l}
\text { fruit, Don't you love ma? } \\
\text { Doganay: of cowse. I love you. But when you eat }
\end{array} \\
& \text { the forbidden you con dea. Nounhter eat the for bididor } \\
& \text { froit yester do } y \text {. But she is very healty } \\
& \text { Doganay: ok! Honey! Let's eat the forbidon froit }
\end{aligned}
$$


International Journal of Current Approaches in Language, Education and Social Sciences

The effects of epics on intercultural awareness of second language learners

CALESS 2021, 3 (2), 265-299 at school of foreign languages

\section{Appendix IX}

DERS GŌNCESI

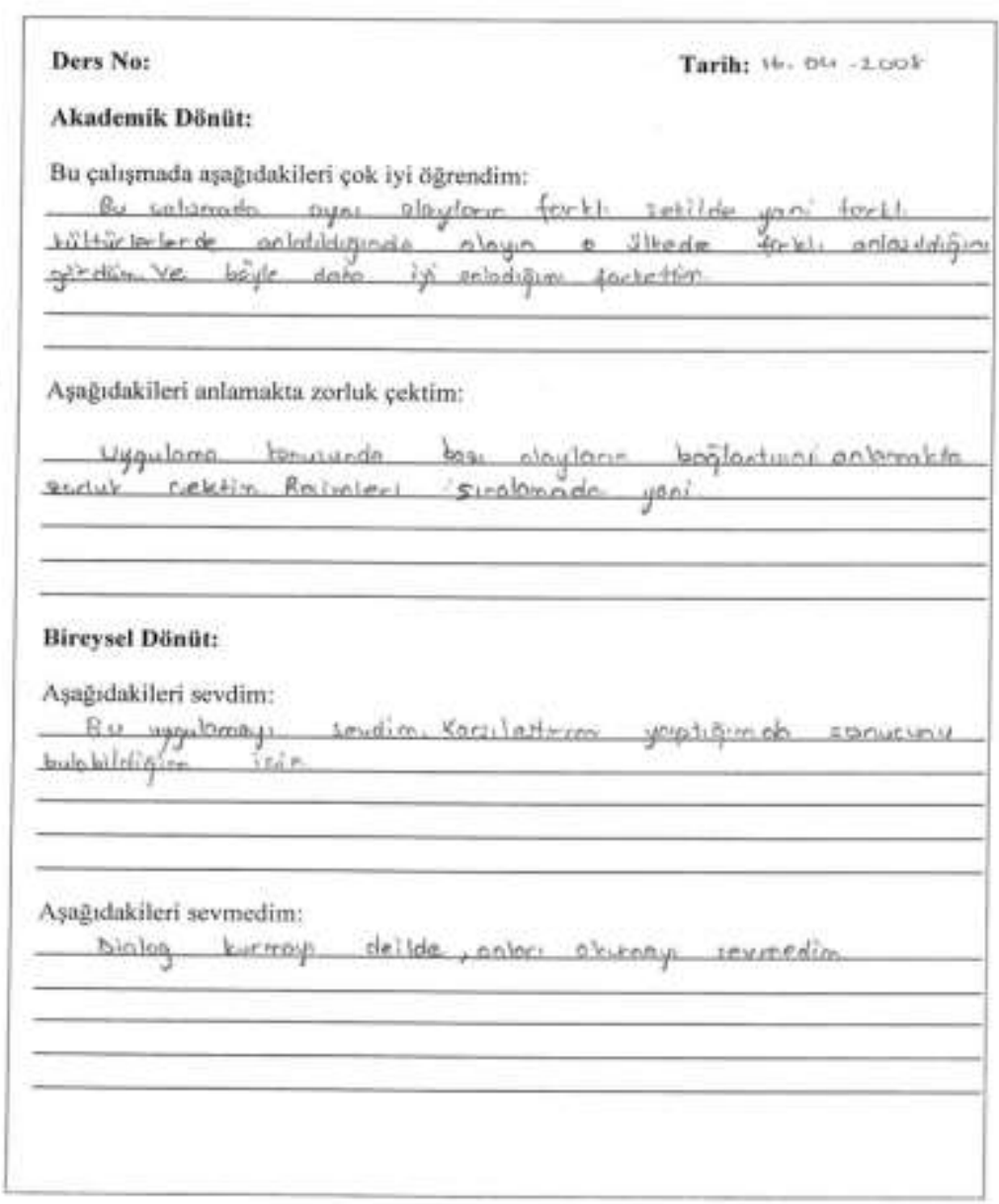

